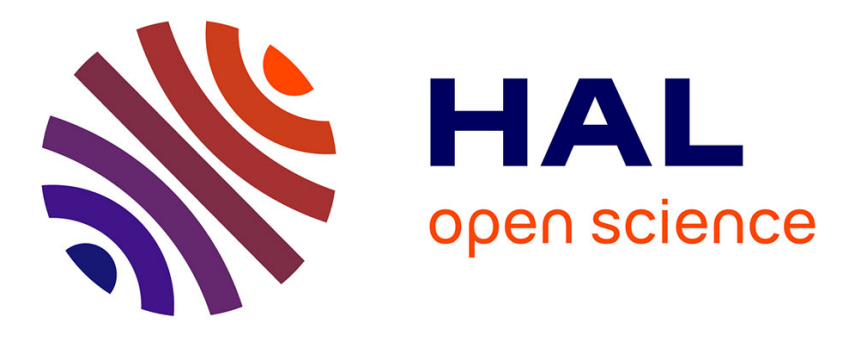

\title{
Imposing a Norm: The Invisible Marks of Copy-Editors
}

Linda Pilliere

\section{To cite this version:}

Linda Pilliere. Imposing a Norm: The Invisible Marks of Copy-Editors. Linda Pillière; Wilfrid Andrieu; Valérie Kerfelec; Diana Lewis. Standardising English: Norms and Margins in the History of the English Language, Part III n 13, Cambridge University Press, pp.251-276, 2018, 9781108120470. 10.1017/9781108120470] . hal-01995846

\section{HAL Id: hal-01995846 https://hal-amu.archives-ouvertes.fr/hal-01995846}

Submitted on 23 Mar 2019

HAL is a multi-disciplinary open access archive for the deposit and dissemination of scientific research documents, whether they are published or not. The documents may come from teaching and research institutions in France or abroad, or from public or private research centers.
L'archive ouverte pluridisciplinaire HAL, est destinée au dépôt et à la diffusion de documents scientifiques de niveau recherche, publiés ou non, émanant des établissements d'enseignement et de recherche français ou étrangers, des laboratoires publics ou privés.

\section{(ㅇ)(1) $\$$}

Distributed under a Creative Commons Attribution - NonCommercial - NoDerivatives| 4.0 
This material has been published in revised form in Standardising English: Norms and Margins in the History of the English Language edited by Linda Pillière, Wilfrid Andrieu, Valérie Kerfelec and Diana Lewis [https://doi.org/10.1017/9781108120470]. This version is free to view and download for private research and study only. Not for redistribution or re-use. (C) CUP 



\section{Imposing a Norm: The Invisible Marks of Copy-Editors}

\section{Linda Pillière}

Introduction

Printing and publishing have historically played an important role in standardising the English language, but we are usually unaware of the numerous changes made to a manuscript before it reaches the bookshop. Indeed, most readers probably do not even notice the name of the editor and would be surprised, even taken aback, to discover that a novel is more of a collaborative effort than first assumed.

However, there are memorable occasions when editorial modifications do become visible, the furore over the US publication of Harry Potter and the Sorcerer's Stone being one of the more recent, ${ }^{1}$ and the relatively frequent existence of American English (AmE) editions of British novels provides evidence of editorial interventions. Many of the modifications are instances of 'verbal hygiene' (Cameron 1995) and reveal the important role played by copyeditors. Yet, despite the growing interest in the role of copy-editing (Wates and Campbell 2007; Nunn and Adamson 2012; Owen 2013), studies have tended to focus on publishing in academic journals. Few have drawn attention to the omnipresence of modifications in fiction and even fewer to the gatekeeping role that many copy-editors assume. This chapter examines the interplay between usage/style guides and editorial practice, and seeks to examine whether copyeditors contribute to establishing a written norm.

In earlier research I focused on the changes introduced into the texts of British novels re-published in the United States between 1980 and 2010 (Pillière 2010, 2013). The corpus comprised 60 novels from various genres: Booker Prize winners, children's fiction, science fiction, biography, romance and travelogues. Some changes were obviously dialectal due to spelling differences (center instead of centre), punctuation differences (the use of single or double inverted commas to introduce speech), grammatical differences (gotten instead of got) or lexical differences (candy instead of sweets). All these changes exposed the important role played by editors (I use the term loosely here),

I would like to thank the anonymous members of Copyediting-L, ACES, SfEP and AFEPI without whose help the survey would not have been possible 
but would have been clearly visible to any attentive reader, without the original edition to hand. Other differences were less straightforwardly 'dialectal', less visible and less easily explained. It was also difficult to ascertain whether the changes had been made by the author after initial publication in the United Kingdom or by the US editor. It was equally difficult to tell whether these modifications would have been approved by all copy-editors or whether they were specific to one publishing house or even one copy-editor.

In order to discover why these changes might have been made, what role, if any, might have been played by style and usage guides and how these changes might affect written English, I designed an online survey which presented participants, all of whom were or had been professional copy-editors, with extracts from the corpus that featured changes to grammatical structures and to information packaging in the two editions. In each case the participants were asked to state a preference, if any, for one of the two extracts. They were also asked to give reasons for their choice. It was thus possible to test whether the modifications were identified as dialectal differences, as grammatical rules, as style preferences or simply an individual copy-editor's choice of norm.

The first part of this chapter briefly presents the copy-editor's role within the publishing process, followed by an overview of style and usage guides used by copy-editors. The two grammatical points under investigation are then presented from the perspective of style/usage guides and scholarly articles. A presentation of the research design and the results of the survey follow. Finally the data are analysed and the findings discussed.

\section{The Role of Copy-Editors within the Editorial Process}

Copy-editing is often considered to be 'the heart of the editorial process' (Mackenzie 2011, p. 161), although copy-editors' exact role can vary according to the type of text they are working on, as can the job title. Some publishers distinguish between copy-editors and line editors (Cavin 1993, p. 199). The former works on the style and creative content, whereas the latter intervenes at the micro-level of the text, checking it carefully for spelling, punctuation and grammar and ensuring that references and quotations are accurate, although there is often some overlap. Other definitions focus on the process, rather than the job title. The Chicago Manual of Style distinguishes between two kinds of editing: mechanical editing or 'the consistent application of a particular style to a written work' and substantive editing, which 'involves rewriting to improve style or to eliminate ambiguity, reorganizing or tightening, recasting tables, and other remedial activities' (2010, 2.46 and 2.47). A further distinction concerns the levels of editing - light, medium and heavy - although what these terms refer to may again vary slightly from one publisher to another. Light copy-editing (or baseline) is generally correcting indisputable grammatical mistakes; medium copy-editing covers errors in syntax, usage and any infelicitous turns of phrase; 
heavy copy-editing involves a greater degree of rewriting (Einsohn 2006, p. 12). For the purposes of this chapter, I use the term 'copy-editor' throughout to refer to the profession, as the main aims remain very similar: 'to remove any obstacles between the reader and what the author wants to convey and to find and solve any problems before the book goes to the typesetter' (Butcher 2006, p. 1). The copy-editor's chief concerns comprise " "the $4 \mathrm{Cs}$ " - clarity, coherency, consistency, and correctness - in service of the "Cardinal C": communication" (Einsohn 2006, p. 3). Far from acting on a personal whim, copy-editors rely heavily on style and usage guides to help them achieve a 'correct' version free from awkwardness, inaccuracy and errors.

\section{$3 \quad$ Style Guides and Usage Guides}

The distinction between style guides and usage guides is not always clear-cut (see Tieken, Chapter 10, for a fuller discussion). Strunk and White's Elements of Style is really a usage guide, and some works even claim to be both, such as The New York Times Manual of Style and Usage and The American Heritage Guide to Contemporary Usage and Style.

However, style and usage guides differ in many important respects. Firstly, style guides are aimed at professionals. A publishing house will have its own mandatory in-house style guide, thus imposing a consistent style throughout a text. These guides are concerned with ruling on specific spellings (-ise or ize) or punctuation. Publishers may also require copy-editors to follow a more complete guide such as the The Chicago Manual of Style or may publish their own such as The Random House Handbook or The Cambridge Handbook for Editors, Copy-editors and Proofreaders. Certain professions or academic disciplines use a specific style manual or guide. Journalists turn to the AP Stylebook for guidance; students in the humanities to the MLA Handbook. A usage guide, in contrast, provides rules and advice 'to enable its user to make choices between linguistic features that can be functionally equivalent in a given context' (Weiner 1988, p. 173). So while a style guide is used by professionals, a usage guide is consulted by anyone who feels insecure about points of usage.

Despite the potentially different readership, the grammatical content of style guides often resembles the prescriptivism of usage guides. Advice on when to use which or that, recommendations on dangling participles or the use of only, appear in both style and usage guides. It is the tone and aim that are different. While an in-house style sheet provides a list of do's and don'ts with no personal comment and a style guide, such as The Chicago Manual of Style, will generally avoid using the first person, a usage guide gives clear opinions on matters of usage, using the modal should and imperatives to convince its readers (Cameron 1995, p. 67). As the writers of Merriam-Webster's Dictionary of English Usage (1994, p. 7a) point out, 'Behind usage as a subject lies a collection of opinions about what English grammar is or should be, about the propriety of using certain 
words and phrases, and about the social status of those who use certain words and constructions.' As a result, usage guides introduce a moral tone which is absent from style guides.

If a style guide aims at consistency, a usage guide promotes clarity (though the two are not mutually exclusive), and clarity is achieved through concision: 'as long as it's accurate, the briefest way of phrasing an idea is usually best because the brevity enhances speed, clarity, and impact' (Garner 2009, p. xviii). Succinctness is therefore desirable: the authors of Style: Lessons in Clarity and Grace devote a whole chapter to the art of concision, advocating the deletion of words that 'mean little or nothing' or that 'repeat the meaning of other words' (Williams and Bizup 2014, p. 139), while Strunk and White insist that 'vigorous writing is concise' $(2009$, p. 25). The metaphor 'good style is healthy and strong' is echoed most clearly in Sword's (2007) The Writer's Diet, which aims to produce lean and fit prose.

If clarity means telling things straight, wordiness suggests dishonesty. For Orwell (1946, p. 357), 'the great enemy of clear language is insincerity. When there is a gap between one's real and one's declared aims, one turns instinctively to long words and exhausted idioms.' Other usage guide writers may not go as far as equating a clear, concise style with honesty, but they do associate correct usage with good manners. Writing lengthy sentences is 'an unfriendly act' (Cutts 1995, p. 41); 'unclear writing is a social problem' (Williams and Bizup 2014, p .6), and the would-be writer should realise that '[s]ome writers ... claim to be sickened or disgusted when they find words misused, and it is only civil to spare them distress' (Cook 1985, p. 163).

A clear style is thus held up as an ideal, both moral and stylistic. However, even style sheets sometimes adopt a moral tone. Writing about the house style of the Guardian newspaper, Marsh remarks that 'part of it is about consistency, trying to maintain the standards of good English that our readers expect ... But, more than anything, the Guardian style guide is about using language that maintains and upholds our values.' ${ }^{2}$ The clear link between language and morality leads to a style guide being elevated to 'holy text' (Pullum 2004, p. 7), the undisputed authority of what is and what is not considered to be acceptable.

One of the striking characteristics of both style and usage guides is their disregard or apparent lack of knowledge of current linguistic research. Usage guide writers are rarely linguists themselves (John Humphrys is a radio news presenter, Bill Bryson a writer, Bryan Garner a lawyer). It is perhaps then hardly surprising that usage guides offer little grammatical explanation as to why they prefer one form to another. As the authors of Merriam-Webster's Dictionary of English Usage point out,

A fairly large number of these opinions have been with us long enough to be regarded as rules or at least to be referred to as rules. In fact, they are often regarded as rules of 
grammar, even if they concern only matters of social status or vocabulary selection. And many of these rules are widely believed to have universal application, even though they are far from universally observed. (1994, p. 7a)

Finally, it is worth emphasising that there are fundamental differences between the teaching of grammar in the US and the UK educational systems. While English grammar disappeared from the British school curriculum from the late 1960s, leading Aarts, Clayton and Wallis (2012) to talk of the 'grammar gap', school grammars and college handbooks, heavily influenced by usage guides such as Strunk and White, play a more important role in the United States. Zwicky, writing on Language Log (2006), points out the dangers of blindly following such guides:

People think that rules are important, and they are reluctant to abandon things they were taught as children, especially when those teachings were framed as matters of right and wrong. They will pass those teachings on. They will interpret denials of the validity of such rules - even denials coming from people like Garner and Fiske, who are not at all shy about slinging rules around - as threats to the moral order and will tend to reject them.

\section{The Usage Points Chosen for Analysis}

In order to discover copy-editors' motivations for textual modifications, my questionnaire contained several usage differences, but for the present chapter I focus on two of them for the following reasons. While it is generally agreed that the first difference, the use of that rather than which in restrictive relative clauses, is a prescriptivism-related change (Bohmann and Schultz 2011; Curzan 2014), those responsible for enforcing the rule are not so clearly identified. Bohmann and Schultz imply that it is the writers themselves (2011, p. 98), although they do suggest in their conclusion that 'the changing style sheets and policies of individual editorial boards may provide rewarding results for contextualizing the probabilistic developments extracted from corpus linguistic analyses' (2011, p. 99). Cameron (1995, p. 56), in contrast, quoting Stainton in The Fine Art of Copy-editing, suggests that the distinction may be on the way out. One of the aims of the questionnaire was to investigate which of the two hypotheses is the closer to reality and how far copy-editors are responsible for maintaining this distinction. The second structure that I focus on is the elimination of there is/there are. This point has received less attention and also provides a clear example where linguists and usage guides differ in their analysis.

\subsection{Which and That in Restrictive Relative Clauses}

A restrictive relative clause is one where the information contained in the dependent clause is integrated both syntactically (no comma) and prosodically 
(no pause) (Huddleston and Pullum 2002, p. 63). The MHRA Style Guide (2008, p. 25) gives the following examples:

The family had two cats, which slept indoors, and a dog.

The family had two cats which slept indoors and one which went out at night.

In the first sentence, the non-restrictive relative provides information that is considered supplementary, while in the second the relative restricts or defines what the antecedent (cats) denotes.

While both which and that appear in restrictive relative clauses in spoken English, various corpora studies have commented on and convincingly demonstrated that which is being replaced by that in written English (Biber et al. 1999; Leech et al. 2009; Bohmann and Schultz 2011). This substitution is happening at a faster rate in American English (Bohmann and Schultz 2011, p. 96), so it is hardly surprising that which is frequently replaced by that in AmE editions of British English (BrE) novels. Note that this rule does not apply to all relative clauses. In cases of pied-piping, when the relative pronoun is preceded by a preposition, which will be retained in the US edition. Similarly, the preference for which prevails if that has previously been used or if which is preceded immediately by a demonstrative pronoun.

\subsection{Which and That: A Dialectal Difference?}

In their translation of the Cambridge International Dictionary of English, Heacock and Cassidy remark that they felt it necessary to replace which with that in restrictive clauses because although it was 'perfectly acceptable in American English', it was 'used with such abandon in British English that (it) in fact marked the text as being British' (1998, p. 95). Similarly, Hargraves comments that 'Americanizing editors can usually do no wrong in systematically changing which to that in defining clauses of British English' (2003, p. 53). Biber et al. (1999, p. 283) suggest that belongs to a more informal style and that colloquial forms are more prevalent in the United States. Yet this insistence on dialectal difference is misleading. Equally misleading is The Chicago Manual of Style Online when it states, 'In British English, writers and editors seldom observe the distinction between the two words', the suggestion here being that writers themselves choose that over which because of dialectal differences.

It is not necessarily the case that an AmE writer will use that in a restrictive relative clause. Nor is it necessarily the case that a publishing house will impose the which/that distinction. One Book/Five Ways (1977), records the publishing history of a single manuscript No Time for Houseplants that was sent to five North American university presses: the University of Chicago Press, MIT Press, University of North Carolina Press, University of Texas Press, and University 
of Toronto Press. The five edited manuscripts reveal very different attitudes regarding the use of which. In the original manuscript, the author, an American, frequently uses which in a restrictive clause. Two out of the four university presses in the United States, the University of Texas Press and University of Chicago Press, chose mostly to leave which untouched:

Remember also to avoid spraying plants which have been standing in direct sunlight. (pp. 25 and 207)

Plants which produce rhizomes may be propagated by dividing the rhizomes. (pp. 27 and 210)

Stem cuttings which cannot be rooted in water are rooted in perlite. (pp. 27 and 209)

The MIT Press and the University of North Carolina Press, in contrast, both substituted that:

Remember also to avoid spraying plants that have been standing in direct sunlight. (pp. 83 and 141)

Stem cuttings that cannot be rooted in water are rooted in perlite. (pp. 85 and 143)

Plants that produce rhizomes may be propagated by dividing the rhizomes. (pp. 86 and 143)

In other words, when One Book/Five Ways was published, the use of that in restrictive relative clauses was clearly being imposed by some editors, but not necessarily practised by all Americans nor even by all publishing houses. This suggests that, rather than being a dialectal difference, the use of that or which is evidence of the copy-editor following the directives of a style sheet or usage guide.

American style and usage guides clearly advocate the use of that, and none more adamantly than Strunk and White: 'Careful writers, watchful for small conveniences, go which-hunting, remove the defining whiches, and by so doing improve their work' (2009, p. 59). The Chicago Manual of Style offers similar advice:

In polished American prose, that is used restrictively to narrow a category or identify a particular item being talked about... Which is used non-restrictively - not to narrow a class or identify a particular item but to add something about an item already identified... Which should be used restrictively only when it is preceded by a preposition. (15th edn, p. 230)

Other style and usage guides such as The American Heritage Book of English Usage are a little more cautious: 'this use of which with restrictive clauses is very common, even in edited prose. If you fail to follow the rule in this point, you have plenty of company' (1996, p. 39).

To understand why this rule has become so deeply entrenched, we have to remember the importance of clarity for usage guides. If all that separates a 
restrictive relative from a non-restrictive relative is a comma, then its accidental omission or misplacement could alter the meaning or render it ambiguous. Fowler is of the opinion that "[i]f writers would agree to regard that as the defining relative pronoun, and which as the non-defining, there would be much gain both in lucidity and in ease' (1926, p. 774).

Added to this commitment to clarity is a preference for a neat binary system. The rule for using that in a restrictive relative may originate 'from a desire for grammatical symmetry’ (Hinrichs, Szmrecsanyi and Bohmann 2005, p. 808). As which is the only relativiser to be used in a non-restrictive relative clause, it is less 'messy' if only one relativiser (that) is used in a restrictive relative clause.

However, this desire to regularise the language has not gone unchallenged (Pullum 2012; Liberman 2012). The semantic difference between the two types of relative needs to be taken into account. When there are two separate assertions (as in a non-restrictive relative), the information in the first assertion must be sufficiently newsworthy to be 'an independent and self-sufficient piece of information' (Huddleston 1984, p. 399). The sentence 'Yesterday John saw an animal, which resembled his great-uncle Fred' is 'slightly odd' because 'John's seeing an animal would not really be newsworthy in most situations that we can imagine' (Baker 1995, p. 334).

\subsection{Use of there is/there are: Empty Words?}

The debate over the use of there is/are further underlines the dividing line between style/usage guides and linguists.

4.3.1 What the Arbiters of Usage Say Although the structure there is/are (henceforth existential there) is commonly used in both written and spoken English, it is shunned by style and usage guides. Garner (2009, p. 811) quotes a number of style/usage guides which, even if they accept that the structure may be common and idiomatic, advocate avoiding it whenever possible on the grounds that existential there adds extra words but no meaning and is a weak, tame way of beginning a sentence. Garner himself advocates using existential there only if 'the writer is addressing the existence of something' (2009, p. 811); otherwise there is and there are are simply 'signals of clutter' and, as Payne remarks, 'nothing saps the vitality of language as quickly as meaningless clutter' (quoted in Garner 2009, p. 811). While a sentence without existential there 'is clearly less wordy, it is also more direct and more forceful' (Adams and Tickle 1994, p. 166); using existential there results in a sentence lacking vigour or strength: 'Many a tame sentence of description or exposition can be made lively and emphatic by substituting a transitive in the active voice for some such perfunctory expression as there is or could be heard' (Strunk and White 1999, p. 18). Strunk and White advocate replacing 
'there were a great number of dead leaves lying on the ground' with 'dead leaves covered the ground' and 'the sound of the falls could still be heard' with 'the sound of the falls still reached our ears' (1999, p. 18). Unfortunately, their comment seems to equate existential there with the passive voice, and this confusion can be found in other grammars or style/usage guides that quote the two authors. In a post entitled 'Drinking the Strunkian Kool-Aid' on Language Log, Pullum (2009) suggests that 'a large number of the ten million or more Americans who bought The Elements of Style have been confused by Strunk and White's less than clear labelling of the passive voice' and that this is why so many errors prevail still today. I return to this point in my analysis of the survey results.

The debate over existential there is not really one of grammatical usage, but another example of stylistic prescriptivism (Curzan 2014). This is probably why the structure does not feature in professional style guides such as The Associated Press Stylebook, Butcher's Copy-editing, or New Hart's Rules. Most usage guides accept that the structure is grammatical, but consider it to be 'weak' or 'clumsy'. However, Williams and Bizup do acknowledge that 'experienced writers commonly begin a paragraph with there to introduce new topics and concepts that they develop in the sentences that follow' (2014, p. 97), and that point is one echoed by linguists.

4.3.2 Existential there: Usage Patterns Uncovered by Linguists Although the term dummy there (Radford 1997) might give credence to the style/usage guides' belief that existential there is meaningless, linguists have also underlined its pragmatic role. Using existential there displaces the subject into a postverbal position, which gives it end-focus (Erades 1975), thereby enabling the speaker 'to focus the hearer's awareness on the referent of the construction' (Lakoff 1987, p. 545) or to 'tell the addressee that she must be prepared to divert her attention towards a new item of information' (Breivik and Swan 2000, p. 28). A similar analysis is found in Bolinger (1977, pp. 9394) and later studies by Cheshire (1999) and Sasaki (1991). Existential there is therefore one of several non-canonical structures that are different from their own basic or canonical counterparts not in 'truth conditions', but 'in the way the content is presented' (Huddleston and Pullum 2002, p. 1365); that is, in the way information is packaged (Chafe 1976; Breivik 1981; Erdmann 1990; Lambrecht 1994).

\section{$5 \quad$ Methodology}

The questionnaire sought to address three questions. Were the modifications made to British English $(\mathrm{BrE})$ texts considered necessary by all AmE copy-editors? Did BrE editors evaluate the changes that were made differently 
Table 13.1 Personal characteristics of respondents

\begin{tabular}{|c|c|c|c|c|c|c|c|}
\hline & & \multicolumn{6}{|c|}{ Age group } \\
\hline \multicolumn{2}{|c|}{ Characteristic } & $18-29$ & $30-39$ & $40-49$ & $50-59$ & over 60 & Total \\
\hline \multirow[t]{2}{*}{ Gender $\%$} & Male & $1.66 \%$ & $2.21 \%$ & $4.42 \%$ & $6.08 \%$ & $7.18 \%$ & $21.55 \%$ \\
\hline & Female & $3.87 \%$ & $13.81 \%$ & $15.47 \%$ & $18.78 \%$ & $26.52 \%$ & $78.45 \%$ \\
\hline \multirow[t]{2}{*}{ Nationality \% } & US & $6.77 \%$ & $18.79 \%$ & $19.55 \%$ & $20.30 \%$ & $34.59 \%$ & $100.00 \%$ \\
\hline & $\mathrm{BI}$ & $2.08 \%$ & $8.33 \%$ & $20.84 \%$ & $37.50 \%$ & $31.25 \%$ & $100.00 \%$ \\
\hline \multicolumn{2}{|c|}{$\%$ of total responses } & $5.52 \%$ & $16.03 \%$ & $19.89 \%$ & $24.86 \%$ & $33.70 \%$ & $100.00 \%$ \\
\hline
\end{tabular}

from AmE copy-editors? How far did the choice of copy-editors reflect the advice and rules of style/usage guides?

The aim was to reach a broad spectrum of copy-editors on both sides of the Atlantic. Various copy-editing associations and forums were contacted by email and given the link to the questionnaire used in this study: Copy-editing- $L$, a listserv for copy-editors; American Copy Editors Society (ACES); The Society for Editors and Proofreaders (SfEP); The Association of Freelance Editors, Proofreaders and Indexers (AFEPI). In addition, the link to the questionnaire was posted on the Facebook page of Editors'Association of Earth.

A total of 229 responses were received. For the purposes of this chapter, I selected responses on the basis of answers to 10 demographic questions. The selected respondents were born in either the United States or the British Isles (BI), have lived there for 20 years or longer, and are, or have been, professional copy-editors. This resulted in a total of 181 respondents (48 BI and $133 \mathrm{US}$ ).

\subsection{Characteristics of the Participants}

In terms of gender, 142 of the respondents were female and 39 male. The variable Gender in relation to Age Group and Origin can be seen in Table 13.1.

The figures are reported in percentages. The bottom line gives the total percentage for all the respondents taking part for each age group and shows that the percentage of respondents increases with age. Only 39 respondents belonged to the age groups (18-29 and 30-39), while 106 respondents were aged 50 or over.

For the purposes of the present study the variable Education has not been taken into account, since all the informants had attended some form of higher education. This also suggests one reason why there are fewer respondents in the 18-29 age group, as most will have entered the profession in their late twenties. The variable Gender was not considered for the purposes of this chapter, but the higher number of female participants $(78.45 \%)$ may be due to the fact that many copy-editors are freelancers, working from home. Given the various 
Table 13.2 Use of style and usage guides in relation to origin

\begin{tabular}{|c|c|c|c|c|c|c|c|c|}
\hline & & \multicolumn{7}{|c|}{ Style guide } \\
\hline & & CMOS & APA & AP & MLA & SW & Oxford & Cambridge \\
\hline \multirow[t]{2}{*}{ Nationality $\%$} & US & $80.45 \%$ & $34.58 \%$ & $28.57 \%$ & $30.07 \%$ & $44.36 \%$ & $0.75 \%$ & $0 \%$ \\
\hline & $\mathrm{BI}$ & $66.66 \%$ & $39.58 \%$ & $4.16 \%$ & $31.25 \%$ & $16.66 \%$ & $54.16 \%$ & $29.16 \%$ \\
\hline \multicolumn{2}{|c|}{$\%$ of total responses } & $76.79 \%$ & $35.9 \%$ & $21.54 \%$ & $30.38 \%$ & $37.01 \%$ & $14.91 \%$ & $7.73 \%$ \\
\hline
\end{tabular}

terms used by respondents to refer to their place of birth and residence (UK, Britain, England, Scotland, Northern Ireland, Ireland), I chose to group these answers under the single heading British Isles.

Respondents were also questioned on the style and usage guides used. It was impossible to provide a full list of all the style guides, and as the survey aimed at discovering whether US copy-editors were influenced by specific style guides, the list provided focused on style guides identified from the pilot study: The Chicago Manual of Style (CMOS), Publication Manual of the American Psychological Association (APA), Modern Language Association Handbook (MLA) and Strunk and White (SW). An open-response question enabling those who wished to add other style guides provided a diversity of answers; the three most popular - The Associated Press Stylebook (AP), Oxford, ${ }^{3}$ Butcher's Copy-Editing (Cambridge) - figure in the results shown in Table 13.2.

Other style guides mentioned included Garner and Fowler. Eighteen respondents mentioned they used the style guide provided by the client or their company.

\subsection{Materials}

The online questionnaire was based on a pilot study conducted the previous year and sent to one specific source: Copyediting- $L$. The pilot study had revealed the need to select the sentences for commentary carefully and to address a wider audience, as few British copy-editors contributed to Copyediting- $L$ and most respondents from Copyediting- $L$ were older than 50. A new questionnaire was devised and sent out for feedback. The comments and suggestions received were incorporated into the final questionnaire, which was designed using Google Forms so the link could easily be accessed across the world, and the results could be easily downloaded into Excel for statistical analysis.

The final questionnaire comprised 14 questions: an initial question on the use of style and usage guides; 12 questions, each featuring two sentences, one from the BrE edition of a novel and the other from an AmE edition, and containing both a closed-response and an open-response question; and a final question that presented a short paragraph from the BrE edition of a short story and asked what modifications, if any, might be made. Examples of the 12 usage questions are to be found in Sections 6.1 and 6.2. The participants were 
informed that the survey's aim was to discover more about textual changes made by copy-editors, but not about the provenance of the sentences, although several of the respondents recognised one or other as being BrE or AmE. The order in which the versions appeared (BrE and $\mathrm{AmE}$ ) was not consistent, and the points I wished respondents to comment on were not highlighted in any way. Proper names were changed to avoid revealing that a particular novel was under scrutiny. Nine literary works published between 1981 and 2001, written by different authors and edited by different publishers, featured in the questionnaire. Although my original corpus of 60 novels provided numerous examples of changes that I suspected were prescriptivism related and influenced by style and usage guides, selecting the sentences to be included in the survey proved difficult. It was necessary to exclude any sentence that also contained another dialectal difference to avoid overlapping choices and to avoid examples that required too much contextual detail or where the use of lexical items was ambiguous.

Among the hypotheses tested were whether copy-editors always replaced which by that in restrictive relative clauses and whether they always removed existential there, the two points retained for analysis here. These questions were then followed by a series of demographic questions regarding gender, education, age, place of birth, number of years spent in an English-speaking country, current profession and types of text that the respondent edited. The final demographic question was included to check whether editing practice varied from one field to another.

Reactions from the respondents were mixed. Some used the open-response question to criticise the sentences and/or the wording or format of the questions. One commented twice that the sentences were 'awful' (US 02 age 5059), and several noted that they would have preferred more context. One BI respondent commented in a private email that 'nearly every publisher and commercial client has their own style guide (plus the European Community, which is quite different again) which may overrule some of the conventional treatments'. Such criticisms would need to be taken into account in producing any future questionnaire. Other respondents emailed me after completing the questionnaire to express their pleasure in taking part. It is therefore safe to conclude that any such survey is likely to provoke both positive and adverse criticism.

Many copy-editors formulated quite lengthy answers to the open-response questions, resulting in the survey taking longer than initially forecast.

\section{6}

Analysis of Results

The results from the questionnaire were fed into an Excel spreadsheet, which enabled the various answers to be classified and summarised. All the responses 
to the open question were organised into thematic networks to discover common themes and differences (Attride-Sterling 2001). A thematic framework was created to classify and summarise the data, with headings and classifications that reflected the approach of both style and usage guides and linguistic grammars, as well as any new themes that appeared from the responses. The data were then compared with the variables Age and Origin, as well as the style and usage guides used by the respondents.

\subsection{Question Regarding this and which in Restrictive Relative Clauses}

Participants were presented with the following question:

Please read the following sentences. Which do you prefer?

a) Jack Brown rode a green Vespa GS scooter that he polished twice a day.

b) Jack Brown rode a green Vespa GS scooter which he polished twice a day.

Informants could choose from the following answers:

I prefer sentence (a).

I prefer sentence (b).

I have no preference. Both are equally acceptable.

I think that neither one is acceptable.

This was followed by an open-response question:

Is there any particular reason for your answer? You can be as brief or as lengthy as you wish.

Both sentences were from White Teeth by Zadie Smith. Sentence (a) was from the AmE edition, sentence (b) the BrE edition. Although the BrE sentence reads as a non-restrictive clause (it is unlikely that the character owned several scooters, one of which he polished twice a day), there is no comma. For the AmE copy-editor there were three possible choices: add a comma or interpret the sentence as being restrictive and either keep which or substitute that.

\subsubsection{Answers to the Closed-Response Question The US and BI} results to the closed-response question are compared in Figure 13.1.

As Figure 13.1 shows, the BI respondents were less categorical about the use of which and that than their US counterparts. While a clear majority of US respondents preferred sentence (a), an equal number of BI informants expressed no preference or preferred (a). The breakdown of the responses in terms of age is shown in Tables 13.3 and 13.4. 


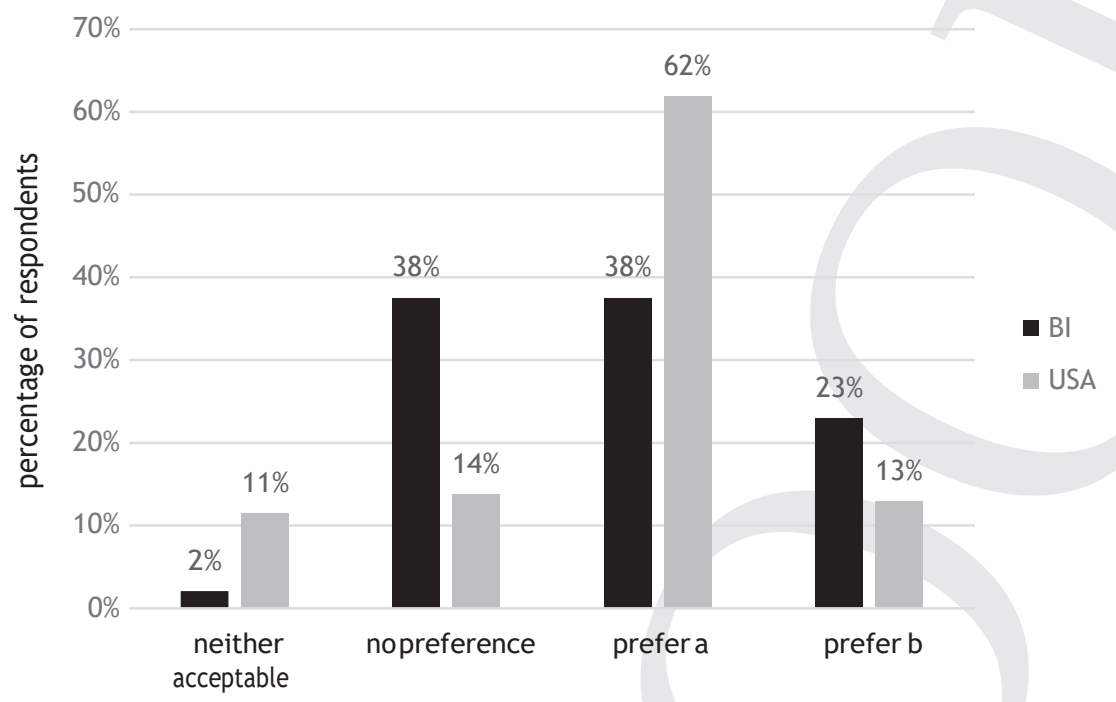

Figure 13.1 Distribution of responses by origin of respondent for which/that

Table 13.3 shows that the US preference for (a) was clear in all age groups. The youngest age group in the survey (18-29) was the least decisive, with 56 per cent (5) preferring (a) and 33 per cent (3) preferring (b). The two youngest age groups in the BI results (see Table 13.4) overwhelmingly expressed no preference: 100 per cent for the 18-29 age group and 75 per cent for the 30-39 age group. These figures appear then to corroborate Cameron's hypothesis that the distinction is disappearing, but given the low number of participants aged 1829 (9 US; $1 \mathrm{BI}$ ) and that there were only 4 BI participants for the 30-39 age

Table 13.3 Correlations between the demographic variable Age and responses for US informants: which and that in relative clauses

\begin{tabular}{lrrrrrr}
\hline \hline & \multicolumn{5}{c}{ Age group } & \% of total \\
Response to each & $18-29$ & $30-39$ & $40-49$ & $50-59$ & over 60 & responses \\
\cline { 2 - 6 } question & $11 \%$ & $4 \%$ & $8 \%$ & $11 \%$ & $17 \%$ & $11 \%$ \\
\hline neither acceptable & $0 \%$ & $16 \%$ & $4 \%$ & $30 \%$ & $11 \%$ & $14 \%$ \\
no preference & $56 \%$ & $64 \%$ & $80 \%$ & $52 \%$ & $59 \%$ & $62 \%$ \\
prefer a & $33 \%$ & $16 \%$ & $8 \%$ & $7 \%$ & $13 \%$ & $13 \%$ \\
prefer b & $100 \%$ & $100 \%$ & $100 \%$ & $100 \%$ & $100 \%$ & $100 \%$ \\
Total & & & & &
\end{tabular}


Table 13.4 Correlations between the demographic variable Age and responses for $B I$ informants: which and that in relative clauses

\begin{tabular}{lrrrrrr}
\hline \hline & \multicolumn{5}{c}{ Age group } & \% of total \\
\cline { 2 - 6 } $\begin{array}{l}\text { Response to each } \\
\text { question }\end{array}$ & $18-29$ & $30-39$ & $40-49$ & $50-59$ & over 60 & responses \\
\hline neither acceptable & $0 \%$ & $0 \%$ & $0 \%$ & $0 \%$ & $6 \%$ & $1 \%$ \\
no preference & $100 \%$ & $75 \%$ & $40 \%$ & $39 \%$ & $20 \%$ & $38 \%$ \\
prefer a & $0 \%$ & $0 \%$ & $40 \%$ & $39 \%$ & $47 \%$ & $38 \%$ \\
prefer b & $0 \%$ & $25 \%$ & $20 \%$ & $22 \%$ & $27 \%$ & $23 \%$ \\
Total & $100 \%$ & $100 \%$ & $100 \%$ & $100 \%$ & $100 \%$ & $100 \%$ \\
\hline \hline
\end{tabular}

group, it would be imprudent to draw any firm conclusions from the data. More important is the reason given for choosing one or other of the sentences, as we see in the next section.

6.1.2 Answers to the Open-Response Question Out of the 133 US respondents, 76 (57\%) offered reasons for this choice (a total of 1189 words), as did $27(56 \%)$ of the $48 \mathrm{BI}$ respondents (a total of 446 words). Overall 26 (21 US; $5 \mathrm{BI}$ ) respondents labelled the type of relative clause, using the following categories: defining (3), descriptive (1) restrictive (9), non-restrictive (14), non-defining (1), essential (3), and dependent (1). ${ }^{4}$ The absence of a comma featured heavily in the US responses, with the term comma occurring 51 times $(67 \%)$, but only 6 times in the BI responses (22\%). It was given as a reason for all four answers. There were some who chose (a) on the grounds that (b) did not have a comma; there were some who chose (b) but added that it needed a comma; those who found neither sentence acceptable did so on the grounds of meaning and the absence of a comma in (b). The frequent reference to the absence or presence of a comma does not really demonstrate any grammatical knowledge as all the style and usage guides mentioned earlier insist on the need to use a comma in a non-restrictive relative. Unlike the US respondents, who generally seemed confident about always adding a comma before which, the $\mathrm{BI}$ informants were less at ease in choosing between the sentences. One person who chose sentence (b) added,

(1) But this is a grey area and I would probably allow either. (BI 26; age over 60)

Another, who chose (a), admitted not being totally sure:

(2) I have followed my instinct as I cannot recall the grammatical rule. (BI 40; age over 60) 
Another who had no preference stated,

I'm not sure that I don't use these interchangeably in some contexts. (BI 23; age 50-59)

Generally, the BI respondents were far less categorical:

(4) The difference is pedantic. (BI 24; age over 60)

(5) A lot of time gets wasted on the that/which question. (BI 32; age 50-59)

Both sets of respondents were aware that usage was different on either side of the Atlantic and offered this as a reason for having no preference:

(6) I believe US English is more strict about using 'that' in this context but in UK English most people are happy with 'that' or 'which' in a restrictive/defining clause. (BI 12; age 40-49)

Depends if it's US or UK English. (US 5; age 50-59)

Others saw the difference as clearly dialectal and as a reason for preferring sentence (a):

(8) I'm American. We set off non-restrictive clauses with a comma. (US 17; age 40-49)

As an American, I greatly prefer that in restrictive relative clauses. (US 21; age 40-49)

Others saw it more as a question of practice or style:

(10) I adhere to the American practice of differentiating between that and which. (US 88; over 60)

Some even admitted only making the distinction because of the norm imposed by style guides:

(11) For an American audience I tend to follow the which/that convention to avoid the accusation that I'm ignorant of it. There's nothing wrong with the BrE convention, though. (US 104; age over 60)

(12) American editing practice would say that sentence b would need a comma, but I know of many highly literate non-editors who would write or say sentence b. Of course if I'm editing for an American publisher, I'll make the text conform to sentence a. (US 87;50-59)

(13) Only because I'm American and CMOS, APA, and AP prefer to distinguish between that and which. I don't personally care. (US 102; age 40-49)

Two US respondents mentioned they had been taught always to use a comma with which 'so it looks wrong to see the "which" without a comma' (US 90; age 50-59). Although only one US respondent referred to 'style/usage/punctuation 
rules', deontic modality was frequent in the US responses: 16 US respondents used needs/need/needed/necessary; 9 used should; 1 used must. Out of the BI respondents only two used necessary, another one used must, and their comments were generally less categorical:

(14) I have followed my instinct (BI 40; age over 60)

(15) It 'sounds' better (BI 30; age 50-59)

\subsection{Answers to the Question on Existential there}

The question regarding existential there followed a similar format to the that/which question, except in this case a short sentence was added to explain the context.

Please read the following sentences. Which do you prefer? (Context: This is an account of a battle and the beginning of a new paragraph)

a) There are three distinct aspects of this enormous battle that appear to make it particularly important in the story of John Smith.

b) Three distinct aspects of this enormous battle appear to make it particularly important in the story of John Smith.

Sentence (a) was taken from Simon Winchester's novel The Surgeon of Crowthorne, and sentence (b) from the US edition The Professor and the Madman.

6.2.1 Answers to the Closed-Response Question The US and BI responses to the closed-response question can be seen in Figure 13.2.

Both US and BI respondents overwhelmingly preferred sentence (b), 74 per cent and 71 per cent, respectively. The correlation between the demographic variable Age and the choice of response was not conclusive, as can be seen in Tables 13.5 and 13.6.

In both tables, the 40-49 age group has the lowest preference for (b) and the highest for (a), but the numbers involved are not high enough to draw any satisfactory conclusions. The variable Age is not taken into account in this section, unless it is considered significant.

6.2.2 Answers to the Open-Response Question Out of the 133 US respondents, 93 (70\%) offered reasons for their choice (a total of 1045 words), as did 37 (77\%) of the $48 \mathrm{BI}$ respondents (a total of 502 words). These numbers were higher than for the previous question. Four US and two BI respondents explained that both were acceptable depending on the context:

(16) It would depend on the exact wording that preceded. (US 3)

(17) Meaning is slightly different, so would depend on context. (BI 1) 


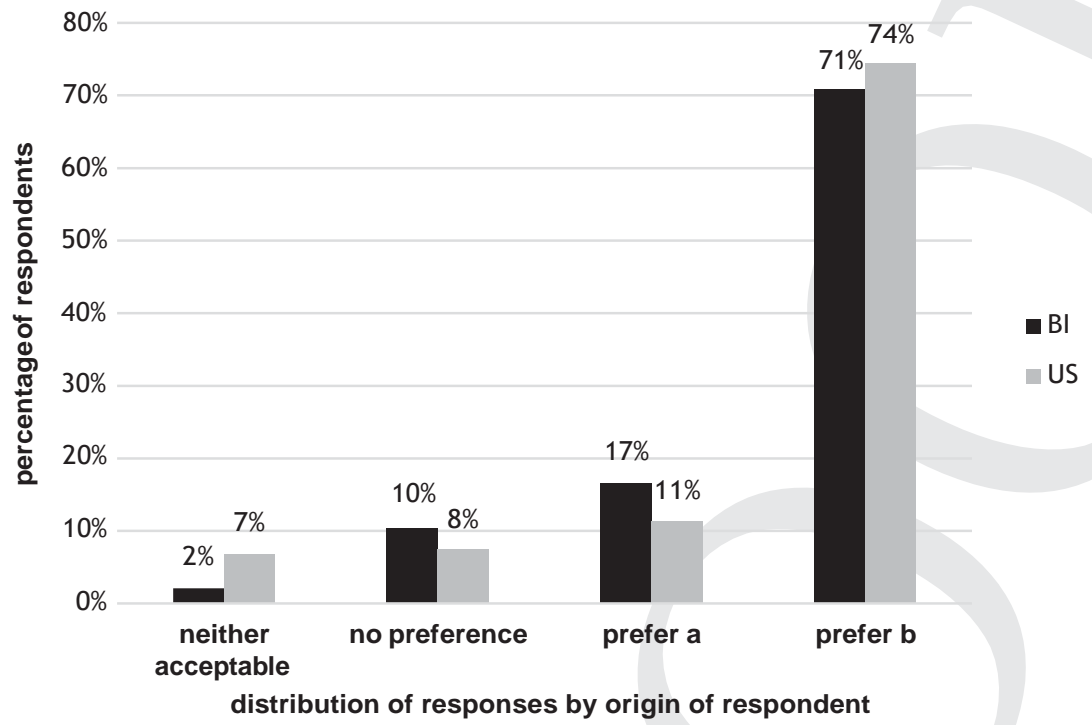

Figure 13.2 Distribution of responses by origin of respondent for existential there

Those who found neither acceptable identified other elements in the sentences that they found problematic, notably the use of appear:

Sentence $\mathrm{a}$ is wordy, and sentence $\mathrm{b}$ uses a confusing verb (appear) that makes it seem like the battle is "appearing". My rewrite "Three distinct aspects of this enormous battle seem to make it particularly important." (US 15)

Table 13.5 Correlations between the demographic variable Age and responses for US informants: existential there

\begin{tabular}{lrrrrrr}
\hline \hline & \multicolumn{5}{c}{ Age group } & \% of total \\
\cline { 2 - 6 } Response to question & $18-29$ & $30-39$ & $40-49$ & $50-59$ & over 60 & $\begin{array}{r}\text { responses } \\
\text { neither acceptable }\end{array}$ \\
\cline { 2 - 6 } no preference & $0 \%$ & $12 \%$ & $11 \%$ & $8 \%$ & $2 \%$ & $7 \%$ \\
prefer a & $0 \%$ & $4 \%$ & $8 \%$ & $8 \%$ & $11 \%$ & $8 \%$ \\
prefer b & $11 \%$ & $0 \%$ & $23 \%$ & $11 \%$ & $11 \%$ & $11 \%$ \\
Total \% & $89 \%$ & $84 \%$ & $58 \%$ & $74 \%$ & $76 \%$ & $74 \%$ \\
\hline \hline
\end{tabular}

Note: Percentages may not add up to $100 \%$ due to rounding. 
Table 13.6 Correlations between the demographic variable Age and responses for BI informants: existential there

\begin{tabular}{lrrrrrr}
\hline \hline & \multicolumn{5}{c}{ Age group } & \% of total \\
\cline { 2 - 5 } Response to question & $18-29$ & $30-39$ & $40-49$ & $50-59$ & over 60 & responses \\
\hline neither acceptable & $0 \%$ & $0 \%$ & $0 \%$ & $0 \%$ & $7 \%$ & $2 \%$ \\
no preference & $0 \%$ & $25 \%$ & $10 \%$ & $11 \%$ & $7 \%$ & $10 \%$ \\
prefer a & $0 \%$ & $0 \%$ & $30 \%$ & $11 \%$ & $20 \%$ & $17 \%$ \\
prefer b & $100 \%$ & $75 \%$ & $60 \%$ & $78 \%$ & $67 \%$ & $71 \%$ \\
Total \% & $100 \%$ & $100 \%$ & $100 \%$ & $100 \%$ & $100 \%$ & $100 \%$ \\
\hline \hline
\end{tabular}

Note: Percentages may not add up to $100 \%$ due to rounding.

a) is clumsy b) is preferable, but 'appear to' is redundant. (BI 6)

(20) Why does the part about appearing reed to be in there? Why so many unnecessary modifiers? Tighten it up. How about this: Three aspects of this battle make it important in the story of John Smith. (US11)

(21) Unclear referent (it). (US 17)

(22) B would be my closest choice. However I would change "in the story of John Smith" to "to the story of John Smith." (US 12)

Those who preferred (a) also invoked the potential ambiguity of appear in sentence (b).

The grammatical labelling of there was more varied than the grammatical labelling of relative clauses. One explanation may be that few US style/usage guides actually label it grammatically, even though they condemn its use. One US informant used the term 'existential'. Others used terms to be found in Garner or other usage guides: 'dummy subject' (US 87) 'placeholder' (US 48) 'false subject' (US 135) and 'expletive' (US 51). There was also identified as belonging to the category of 'filler words' (US 62) or even 'cleft' (BI 23). Existential there was rejected on the grounds that it was in the 'passive voice' (3 informants), and sentence (b) was preferred because it was in the 'active voice' (4 informants). The terms 'passive' and 'active' were used by a further four informants. One even went so far as to say both sentences were passive. Only 2 of these 11 responses came from BI informants. This is the area where the influence of Strunk and White is clearest. The use of 'passive' and 'active' without the accompanying term 'voice' raises another question. It may simply be a shorthand for passive voice and active voice, but it may also be a sign of a general tendency to condemn certain turns of phrase as 'passive' or 'weak', even though there is no passive voice (Pullum 2014). It is also possible that the 


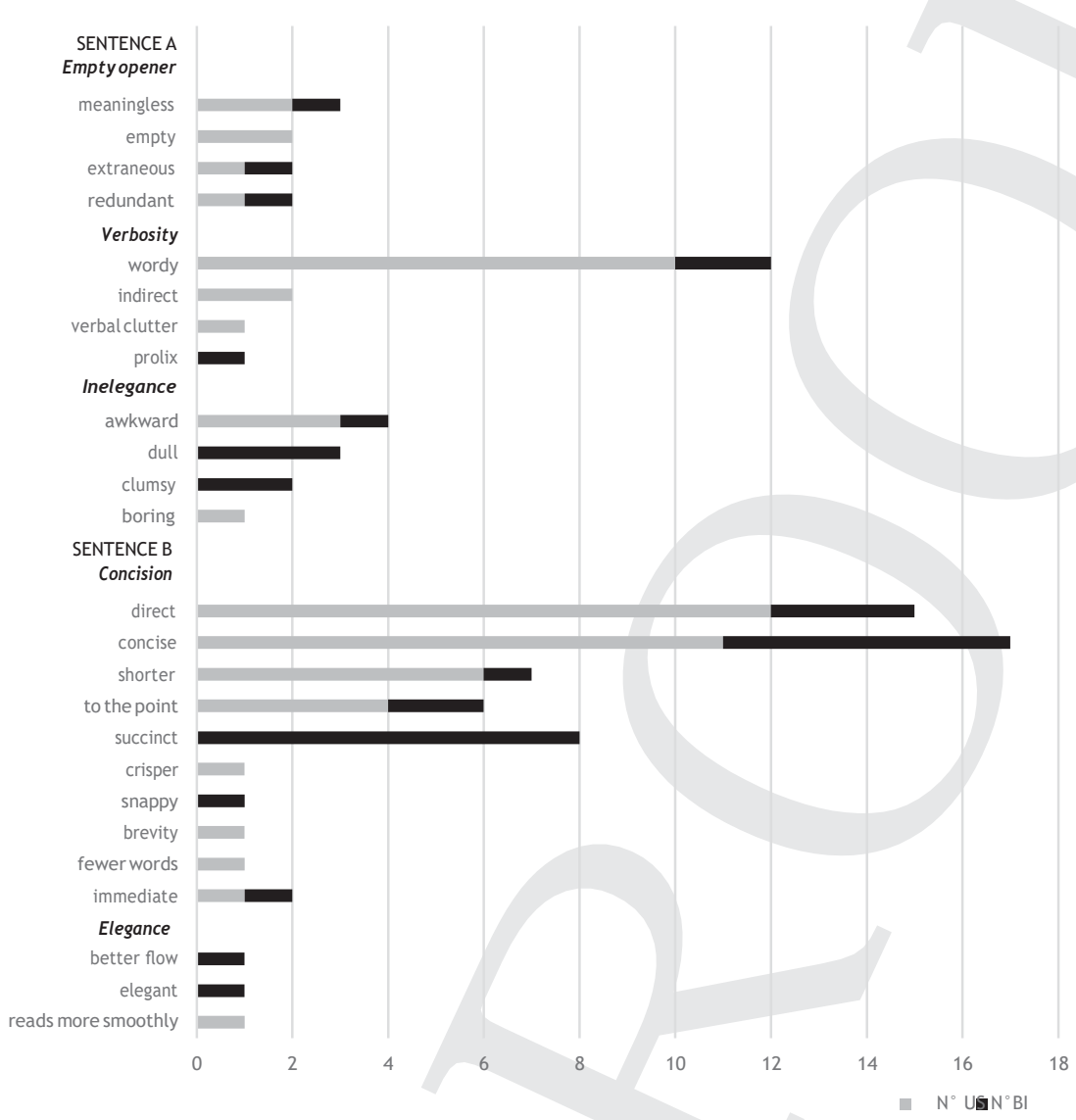

Figure 13.3 Reasons for preferring sentence (a) or sentence (b): existential there

adjectives indirect/direct, which occurred 14 times in the US responses, may be linked to the idea of active and dynamic. The use of direct occurred only twice in the BI responses.

If the preference for sentence (b) was not clearly stated in grammatical terms (unlike the previous question on that and which), 13 US respondents and 1 BI respondent (11\% of overall total) invoked the need to avoid beginning a sentence with there. The reasons given for rejecting sentence (a) are shown in Figure 13.3, grouped under the thematic headings of empty opener, verbosity and inelegance, while the reasons for preferring sentence (b) are given under the headings concision and elegance. The themes inelegance and elegance cover both style and the act of reading. 
The theme 'good style is healthy' was found in US responses that labelled existential there as weak (9), flabby (1) and even a dead structure, and sentence (b) as strong (1) and tighter (2). BI respondents did not use these expressions.

There was little trace of deontic modality. One respondent used ought, but in relation to the use of appear. One US respondent referred to arule:

$$
\text { I think the best rule ever is “omit needless words". (US 96) }
$$

And three US respondents used imperatives or made comments that read as rules learnt off by heart:

$$
\text { Avoid use of "there is/are" whenever feasible. (US 53) }
$$

Avoid "there are" always. (US 52)

Always best to avoid the placeholder "This," "There is," "It was" for the specific. (US 48)

Although a similar tone was found in one BI response, it was downplayed by the modality at the end of the sentence: "There are" is to be avoided if possible.' With two exceptions, all the maxims came from US informants aged over 60 . Two others confessed to having a personal vendetta against existential there:

There are/It is (I've forgotten the technical name for this subjectless construction) is on my search-and-destroy list. It's just weak writing, not a grammatical error. (US 104)

In addition to the use of negative adjectives already mentioned, three US respondents rejected sentence (a) or preferred (b) because they did not 'like' using existential there. Again, these comments were made by respondents aged 50 or over.

The pragmatic role of existential there was recognised by three US informants who preferred sentence (a). The sentence was 'more complete in beginning with "there are" (US 25); there was worked 'better as an establishing structure' (US 21), and while one respondent felt existential there was too 'didactic' to work for the text under consideration, she might use sentence (a) 'in a textbook for young people' (US 90). This link between the use of the existential structure and children's fiction may have led another informant to label it as 'babyish' (US 91). One BI informant (BI 29) also referred to the importance of context and preferred (b) for non-fiction, because it was more 'direct', and another explained that she was 'a technical editor so trained to emphasise conciseness' (US 70). 


\section{Conclusion}

The survey sought to answer three questions. The first addressed the issue of the modifications made to BrE texts for publication in the United States to ascertain whether those changes represented a general tendency or simply the whim of an individual copy-editor. The results of the questionnaire showed that the replacement of that by which and the removal of existential there were common practice and that the majority of the US copy-editors who took part in the survey would have made similar changes. This also confirmed hypotheses found in previous studies (Hinrichs, Szmrecsanyi and Bohmann 2005; Leech et al. 2009; Bohmann and Schultz 2011; Owen 2013).

The second question aimed at investigating the reactions of BI copy-editors to the modifications and at comparing their reactions with those of their AmE counterparts. While US informants clearly preferred the use of that, the BI informants were far more divided. Those who did choose that in preference to which gave similar reasons to their US counterparts: which needed to be preceded by a comma. The removal of existential there was generally approved by both sets of informants, frequently on the grounds of concision.

The final question set out to investigate how far copy-editors were influenced by style and usage guides in their decisions and so, by implication, how far usage guides might influence edited English. While the number of informants was too small to draw any definite conclusions, some important tendencies can be observed which suggest fields for future research. Few copy-editors referred directly to a style or usage guide in answering the questions. However, one or two stated that they were compelled to follow style guides for the distinction between that and which, although they themselves did not personally have a preference. More significantly, perhaps, certain key terms found in usage guides were also used in the open-response questions. One informant mentioned 'verbal clutter' for existential there, a term used by Garner himself in Modern English Usage. Terms such as concise and direct also occurred frequently, and the erroneous linking of existential there with the passive voice seems to confirm Pullum's hypothesis on the pervasive influence of Strunk and White. Several US informants referred to being taught to avoid existential there or to use restrictive that at school. The use of verbs of preference or the statement 'I'm an American and we...' suggests the prescriptive norms have become fully integrated.

While some copy-editors insisted on the need for context, others were far more categorical in applying a rule. The fact that US copy-editors used imperatives and evaluative adjectives, such as those found in usage guides, suggests that they were more influenced by usage guides than their BI counterparts, but this would need further investigation. 
Many of the responses revealed copy-editors' careful reading of texts. They found problems that the survey had not anticipated, such as the ambiguous use of the verb appear, and they offered corrections of the already edited sentences, resulting in an even greater concision.

The reactions of the respondents revealed that they preferred to follow style/usage guides rather than actual usage. One or two copy-editors made it quite clear that if their remit is to change the relativiser then they have little choice. A few informants did mention that existential there played an 'establishing role' at the beginning of a sentence, but the majority of the responses that advocated avoiding there did so on the grounds that there was meaningless, unnecessary or awkward, thus underlining the gap that exists between prescriptivists and linguists.

Finally, in the age of international publishing houses, the question needs to be asked whether the standardisation of edited English, clearly observable in the AmE editions of BrE texts, will not be imposed upon BrE texts themselves, thus removing the need for further editing. Perhaps it is no coincidence that Garner's latest edition of usage is no longer entitled Modern American Usage but Modern English Usage, even though the contents are little altered.

While the role of copy-editors in enforcing written norms has not gone totally unnoticed - Cameron, for example, refers to them as the 'foot-soldiers of hyperstandardization' (1995, p. 53) - their pervasive influence on the text and on an author's style has been difficult to prove. This chapter has sought to throw light on this role, thus underlining the need for further research in this domain.

\section{NOTES}

1. See www.theguardian.com/notesandqueries/query/0,5753,-18387,00.html.

2. See www.guardian.co.uk/commentisfree/2009/aug/31/language-style-guide-clichesgrammar; accessed on 31 October 2012.

3. Oxford is used here as a general term to refer to New Hart's Rules, Oxford Dictionary for Writers and Editors, New Oxford Dictionary for Writers and Editors, and Oxford Guide to Style.

4. Several respondents labelled both sentence (a) and sentence (b) in their answer, which accounts for the fact that more than 26 labels are recorded.

\section{REFERENCES}

Aarts, B., Clayton, D. and Wallis, S. (2012). Bridging the grammar gap: Teaching English grammar to the iPhone generation. English Today, 28 (1), 3-8. doi: 10.1017/S0266078411000599.

Adams, P. D. and Tickle, A. (1994). The HarperCollins Concise Handbook for Writers, New York: HarperCollins.

The American Heritage Book of English Usage. (1996). Boston: Houghton Mifflin. 
Association of American University Presses. (1977). One Book/Five Ways, Los Altos: William Kaufmann.

Attride-Stirling, J. (2001). Thematic networks: An analytic tool for qualitative research. Qualitative Research, 1, 385-405.

Baker, C. (1995). English Syntax, Cambridge, MA: MIT Press.

Biber, D., Johnson, S., Leech, G., Conrad, S. and Finegan, E. (1999). Longman Grammar of Spoken and Written English, Harlow: Longman.

Bohmann, A. and Schultz, P. (2011). Sacred that and wicked which: Prescriptivism and change in the use of English relativizers. Proceedings of the Nineteenth Annual Symposium about Language and Society-Austin. http://studentorgs.utexas .edu/salsa/proceedings/2011/09TLF54-BohmannSchultz.pdf.

Bolinger, D. (1977). Meaning and Form, London: Longman.

Breivik, L. E. (1981). On the interpretation of existential there. Language 57, 1-25.

Breivik, L. E. and Swan, T. (2000). The desemanticisation of existential there in a synchronic-diachronic perspective. In C. Dalton-Puffer and N. Rift, eds., Words: Structure, Meaning, Function - A Festschrift for Dieter Kastovsky, Berlin: Mouton de Gruyter, pp. 19-34.

Butcher, J., Drake, C. and Leech, M. (2006). Butcher's Copy-editing: The Cambridge Handbook for Editors, Copy-Editors and Proofreaders, 4th edn, Cambridge: Cambridge University Press.

Cameron, D. (1995). Verbal Hygiene, London: Routledge.

Cavin, R. (1993). Editing Crime Fiction. In G. Gross, ed., Editors on Editing, 3rd edn, New York: Grove Press, pp. 194-204.

Chafe, W. L. (1976). Givenness, contrastiveness, definiteness, subjects, topics and point of view. In C. N. Li, ed., Subject and Topic, New York: Academic Press, pp. 27-55.

Cheshire, J. (1999). Spoken Standard English. In T. Bex and R. J. Watts, eds., Standard English: The Widening Debate, London: Routledge, pp. 129-148.

The Chicago Manual of Style. (2010). 16th edn, Chicago: University of Chicago Press.

Cook, C. K. (1985). Line by Line: How to Edit Your Own Writing, Boston: Houghton Mifflin.

Curzan, A. (2014). Fixing English: Prescriptivism and Language Change, Cambridge: Cambridge University Press.

Cutts, M. (1995) [2009]. Oxford Guide to Plain English, Oxford: Oxford University Press.

Einsohn, A. (2006). The Copyeditor's Handbook: A Guide for Book Publishing and Corporate Communications, Berkeley: University of California Press.

Erades, P. A. (1975). Points of Modern English Syntax, Amsterdam: Swets and Zeitlinger.

Erdmann, P. (1990). Discourse and Grammar: Focussing and Defocussing in English, Tübingen: Niemeyer.

Fowler, H. W. (1926). A Dictionary of Modern English Usage, Oxford: Clarendon Press.

Garner, B. A. (2009). Garner's Modern American Usage, New York: Oxford University Press.

Garner, B. A. (2010). Grammar and usage. In The Chicago Manual of Style, 16th edn., Chicago: Chicago University Press, pp. 145-237.

Gilman, E. Ward, ed. (1994). Merriam-Webster's Dictionary of English Usage, Springfield, MA: Merriam-Webster. 
Hargraves, O. (2003). Mighty Fine Words and Smashing Expressions, Oxford: Oxford University Press.

Harris, R. (1996). Signs, Language and Communication, London: Routledge.

Heacock, P. and Cassidy, C.-J. (1998). Translating a dictionary from British to American. In H. Lindquist, S. Klintborg, M. Levin and M. Estling, eds., The Major Varieties of English. MAVEN 97. Växjö: Acta Wexionensia, pp. 93-99.

Hinrichs, L., Szmrecsanyi, B. and Bohmann, A. (2005). Which-hunting and the Standard English relative clause. Language 91 (4), 806-836.

Howard, G. (1993). Mistah Perkins - He dead: Publishing today. In G. Gross, ed., Editors on Editing, New York: Grove Press, pp. 56-72.

Huddleston, R. (1984). Introduction to the Grammar of English, Cambridge: Cambridge University Press.

Huddleston, R. and Pullum, G. K. (2002). The Cambridge Grammar of the English Language, Cambridge: Cambridge University Press.

Keneally, T. (1982). Schindler's Ark, London: Hodder and Stoughton.

Keneally, T. (2000). Schindler's List, New York: Scribner.

Lakoff, G. (1987). Women, Fire, and Dangerous Things: What Categories Reveal about the Mind, Chicago: University of Chicago Press.

Lambrecht, K. (1994). Information Structure and Sentence Form, Cambridge: Cambridge University Press.

Leech, G., Hundt, M., Mair, C. and Smith, N. (2009). Change in Contemporary English: A Grammatical Study, Cambridge: Cambridge University Press.

Liberman, M. (2012). Reddit blewit. Language Log. http://languagelog.ldc.upenn.edu/ $\mathrm{nll} / \mathrm{p}=4384$.

MacKenzie, J. (2011). The Editor's Companion, 2nd edn, Cambridge: Cambridge University Press.

Merriam-Webster's Dictionary of English Usage. (1994). Springfield, MA: MerriamWebster.

MHRA Style Guide: A Handbook for Authors, Editors, and Writers of Theses. (2008). 2nd edn, London: Modern Humanities Research Association.

Nunn, R. and Adamson, J. (2012). Editorial and Authorial Voices in EFL Academic Journal Publishing, Tortola: Asian EFL Journal Press.

Orwell, G. (1946). The politics of language. In G. Orwell, Inside the Whale and Other Essays, Harmondsworth: Penguin.

Owen, J. (2013). At the coal-face of standardization: Uncovering the role of copy editors in standardizing the English language. All Theses and Dissertations. Paper 3927. http://scholarsarchive.byu/etd/etd/3927.

Pillière, L. (2010). Cultural transformations in American editions of British novels. In C. Cottenet, J.-C. Murat, and N. Vanfasse, eds., Cultural Transformations in the English-Speaking World, Newcastle: Cambridge Scholars, pp. 15-29.

Pillière, L. (2013). Re-working translations for the American reader - or the domestication of British English translations. In C. Raguet, ed., La cohérence discursive à l'épreuve: traduction et homogénéisation, Paris: Presses Universitaires de la Sorbonne, pp. 45-67.

Pullum, G. K. (2004). Ideology, power, and linguistic theory. http://people.ucsc.edu/ pullum/MLA2004.pdf.

Pullum, G. K. (2009a). 50 years of stupid grammar advice. Chronicle of Higher Education 55 (32), B15. 
Pullum, G. K. (2009b). Drinking the 'Strunkian Kool-Aid'. Language Log. http:// languagelog.ldc.upenn.edu/nll/?p=1485.

Pullum, G. K. (2012). Preaching the incontrovertible to the unconvertible. Language Log. http://languagelog.ldc.upenn.edu/nll/?p=4357.

Pullum, G. K. (2014). Fear and loathing of the English passive. Language and Cоттиnication, 37, 60-74.

Radford, A. (1997). Syntactic Theory and the Structure of English: A Minimalist Approach, Cambridge: Cambridge University Press.

Sasaki, M. (1991). An analysis of sentences with nonreferential 'there' in spoken American English. Word, 42 (2), 157-178.

Smith, Z. (2000). White Teeth, Harmondsworth: Penguin.

Smith, Z. (2001). White Teeth, New York: Vintage.

Strunk, W. and White, E. B. (1999). The Elements of Style, 4th edn, New York: Longman.

Sword, H. (2007). The Writer's Diet: A Guide to Fit Prose, Auckland: Auckland University Press.

Wates, E. and Campbell, R. (2007). Author's version vs. publisher's version: An analysis of the copy-editing function. Learned Publishing, 20, 121-129.

Weiner, E. (1988). On editing a usage guide. In E. G. Stanley and T. F. Hoed, eds., Words: For Robert Burchfield's Sixty-Fifth Birthday, Cambridge: D. S. Brewer, pp. 171-183.

Williams, J. M. and Bizup, J. (2014). Style: Lessons in Clarity and Grace, 11th edn, Harlow: Pearson Education Limited.

Winchester, S. (1999). The Surgeon of Crowthorne, Harmondsworth: Penguin.

Winchester, S. (1999). The Professor and the Madman, New York: HarperCollins.

Zwicky, A. (2006). However, . . . Language Log. http://itre.cis.upenn.edu/myl/ languagelog/archives/003723.html. 